\title{
COVID-19 enfeksiyonu ilişkili pandemi döneminde Ege Üniversitesi Tıp Fakültesi Hastanesi Acil Servisi'ne başvuran hastane dışı kardiyak arrest vakalarının retrospektif değerlendirilmesi
}

Retrospective evaluation of out-of-hospital cardiac arrest patients applying to the Emergency Department of Ege University Medical Faculty Hospital during pandemic period due to COVID-19 infection

$\begin{array}{lll}\text { Sercan YalçınlıD } & \text { Murat Ersel D } & \text { Güçlü Selahattin Kıyan (D) } \\ \text { Funda Karbek Akarca D } & \text { Yusuf Ali Altuncı } & \text { İlhan Uz } \\ \text { Enver Özçete } D & \text { Meltem Songür Kodik D } & \text { Özge Can (D) }\end{array}$

Ege Üniversitesi Tıp Fakültesi Hastanesi Acil Tıp Anabilim Dalı, İzmir, Türkiye

Öz

Amaç: Covid 19 pandemisi direkt ve indirekt olarak sosyal hayatta önemli değişiklikler oluşturdu. Bu çalışmada acil sağlık hizmetleri açısından önemli bir yer tutan hastane dışı kardiyak arrest (HDKA) vakaları değerlendirildi. Pandemi öncesi dönem ile; demografik, etiyolojik ve acil sağlık hizmetlerinin sunumu açısından herhangi bir farklııı olup olmadığının araştırıması amaçlandı.

Gereç ve Yöntem: Acil Servis'e HDKA nedeni ile 2017, 2018, 2019 ve 2020 yıllarının 11 Mart - 01 Haziran tarihleri arasında başvuran hastalar retrospektif olarak değerlendirildi. Pandemi dönemi ve pandemi öncesi dönem olarak iki grup oluşturuldu. Demografik ve klinik özellikler karşılaştırıldı.

Bulgular: Çalışma popülasyonunu 263 hasta oluşturdu. Hastaların \%22,4'ünün (n: 59) 2020, \%25,5'inin (n:67) 2019, \%27,0'inin (n:71) 2018, \%25,1'inin (n:66) 2017 yılında başvuruda bulunduğu belirlendi. Altmış beş yaş altı HDKA sıklığının 2020 yılında $(\% 57,6)$ diğer yıllara göre $(\% 33,3)$ daha fazla olduğu gözlendi (p:0.003). Eşlik eden komorbidite durumu gruplar arasında benzer bulundu. Pandemi döneminde olay yerinde temel yaşam desteği (TYD) uygulama sıklığının diğer dönemlere göre daha fazla olduğu belirlendi (p:0.033). Pandemi döneminde hastaların acil servise daha sık 112 ile getirildiği saptandı (p:0.048). Spontan dolaşımın geri dönüşü (SDGD)'nin pandemi döneminde daha az olduğu gözlendi (\%22- \%37,3, p:0.030). Sağlık çalışanı ile hastaların ilk temas süresinin pandemi döneminde daha kısa olduğu belirlendi (p:0.034).

Sonuç: HDKA vakalarının sıklığında pandemi ve pandemi öncesi arasında değişiklik gözlenmedi. Acil tıbbi hizmet iki grup arasında benzerdi. Pandemi döneminde HDKA hastalarının yaş ortalamasındaki düşüş iyi tasarlanmış çalışmalarla araştırılmalıdır.

Anahtar Sözcükler: Covid-19, hastane dışı kardiyak arrest, acil servis, pandemi.

\section{ABSTRACT}

Aim: Covid 19 pandemic caused significant changes in social life directly and indirectly. In this study, out-of-hospital cardiac arrest (OHCA) cases, which have an important role in emergency medical services, were evaluated. It was aimed to investigate whether demographic, etiological factors and emergency health care outcomes differ from the pre-pandemic period.

Materials and Methods: Patients who admitted to the Emergency Department between March 11 and June 01 of 2017, 2018, 2019 and 2020 for the reason of OHCA were evaluated retrospectively. Two groups were formed as pandemic period and normal period. Demographic and clinical characteristics of the groups were compared.

\footnotetext{
Sorumlu yazar: Sercan Yalçınlı

Ege Üniversitesi Tıp Fakültesi Hastanesi Acil Tıp Anabilim

Dalı, İzmir, Türkiye

E-posta: sercanyalcinli@yahoo.com.tr

Başvuru tarihi: 18.01.2021 Kabul tarihi: 29.01.2021
} 
Results: Totally 263 patients were included, 25.1\% ( $n: 66$ ) in 2017, 27.0\% (n:71) in 2018, 25.5\% (n: 67) in 2019, and $22.4 \%$ (n: 59) in 2020 respectively. We find significant difference between the groups in terms of age (p:0.010). The prevalence of OHCA patients under $<65$ years was higher in 2020 when compared with other years (57.6\% vs $33.3 \%$, p:0.003). Comorbidities were similar between groups. During the pandemic period, the frequency of basic life support at the scene was higher than other periods (p: 0.033). OHCA patients were transported to the ED more frequently with ambulance during the pandemic period ( $p$ : 0.048). The return of spontaneous circulation rates was less during the pandemic period (22\% vs $37.3 \%$, p:0.030). The first contact time between the healthcare professionals and patients was shorter in the pandemic period ( $p: 0.034)$.

Conclusions: There was no difference in the frequency of OHCA between pandemic and nonpandemic period. Emergency medical system service was same between two groups. Decrease in the average age of OHCA patients in pandemic period should be investigated with well-designed studies.

Keywords: Covid 19, out of hospital cardiac arrest, emergency medicine, pandemic

\section{GíRiş}

Türkiye'de Covid 19 enfeksiyonu ilk kez 11 Mart 2020'de saptanmıştır (1). Yurt içinde enfeksiyonun yayılmasını önlemek amacı ile sokağa çıkma kısıtlamaları, yüz yüze eğitimöğretime ara verilmesi, yurt dışı uçuşlarının durdurulması vb. önlemler nüfusun önemli bir kısmının günlük faaliyetlerinde azalmaya yol açmıştır. Bununla birlikte, hastane ve acil servis başvuru sayılarında da azalmalar gözlenmiştir (2, 3). Bu durum kronik hastalığı olan ya da semptomu olmasına rağmen hastane müracaatlarını olası enfeksiyon bulaş riski nedeni ile erteleyen vatandaşların olumsuz yönde etkilenip etkilenmedikleri sorusunu gündeme getirmiştir.

Çalışmamızda, sağlık hizmetine ulaşmama veya ulaşamama durumundan etkilenme olasılığı bulunan bir sonlanım noktası olarak hastane dışı kardiyak arrest (HDKA) vakalarının, 11 Mart - 01 Haziran 2020 tarihleri ile geçmiş son üç yılın (2017, 2018, 2019) aynı aylarına ait verilerin karşılaştırılması yapılarak, demografik, etiyolojik ve acil sağlık hizmetlerinin sunumu açısından herhangi bir farklılık olup olmadığının belirlenmesi amaçlandı.

\section{GEREÇ ve YÖNTEM}

Çalışmamız retrospektif, gözlemsel, tanımlayıcı nitelikte planlandı. T.C. Sağlık Bakanlığı'ndan (2020-06-11T15_26_46) ve Ege Üniversitesi Tıbbi Araştırmalar Etik Kurulundan (Karar No:207.1T/10) araştırma başlamadan önce onay alındı. Hastane elektronik dosya kayıtlarından acil serviste kardiyo-pulmoner arrest nedeni ile müdahale edilen hastaların verileri incelendi.
Hastaların başvuru tarihleri, yaş, cinsiyet, eşlik eden komorbiditeler, arrest nedeni, tanıklı arrest durumu, olay yeri, hastanın başvuru kardiyak ritmi, olay yerinde temel yaşam desteği uygulanıp uygulanmadığı, hastanın hastaneye getiriliş şekli, temel yaşam desteği süresi, defibrilasyon uygulanıp uygulanmadığı, ileri havayolu sağlanma durumu, kardiyo-pulmoner resüsitasyon uygulanma süresi, spontan dolaşım sağlanma durumu, spontan dolaşım sağlanma süresi, acil serviste mortalite, hastaneden taburculuk gibi değişkenler incelendi. Pandemi dönemindeki veriler (11 Mart - 1 Haziran 2020) pandemi öncesi dönem verileri ile (11 Mart - 1 Haziran 2017, 2018, 2019) karşılaştırıldı.

Elektronik dosya değerlendirmesinde hastane içi kardiyo-pulmoner arrest gelişen, 18 yaş altı, Covid 19 Polimeraz Zincir Reaksiyon testi (PCR) sonucu pozitif olan, 112 nakli sırasında kardiyopulmoner arrest gelişen hastalar çalışma dışı bırakıldı.

Veriler SPSS 25.0 programı kullanılarak değerlendirildi. Kategorik değişkenler frekanslar ve yüzdeler kullanılarak verildi. Sürekli değişkenlerin normal dağılıma uygunluğu Shapiro-Wilk testi ile değerlendirildi. Normal dağılan sürekli değişkenler ortalama ve standart sapma, normal dağılmayanlar ortanca ve çeyrekler aralığı kullanılarak verildi. Bağımsız grupların karşılaştırı Imasında normal dağılmayan sürekli değişkenler için Mann Whitney $U$ testi, normal dağılanlar için bağımsız grup $t$ testi uygulandı. Nominal veriler için gruplar arasındaki fark ki-kare testi ile değerlendirildi. " $p$ " değerinin 0,05 'in altında olduğu durumlar istatistiksel olarak anlamlı sonuçlar olarak değerlendirildi. 
Tablo-1. Pandemi öncesi ve sonrası dönemde hastaların demografik verilerinin karşılaştırıması.

\begin{tabular}{|c|c|c|c|c|}
\hline & $\begin{array}{l}\text { Pandemi } \\
\text { Dönemi } \\
\text { n:59 }\end{array}$ & $\begin{array}{l}\text { Pandemi Öncesi } \\
\text { Dönem } \\
\text { n:204 }\end{array}$ & $\begin{array}{l}\text { Toplam } \\
\text { n:263 }\end{array}$ & $\mathbf{p}$ \\
\hline Cinsiyet n(\%): & & & & 0,346 \\
\hline - Erkek & $43(72,9)$ & $133(65,2)$ & $176(66,9)$ & \\
\hline - Kadın & $16(27,1)$ & $71(34,8)$ & $87(33,1)$ & \\
\hline Yaş (ortanca, çeyrekler arası aralık) & $62(54-74)$ & $71(58-82)$ & $69(57-80,5)$ & 0,006 \\
\hline Yaş Grubu n(\%): & & & & 0,003 \\
\hline$\bullet<65$ & $34(57,6)$ & $68(33,3)$ & $102(38,8)$ & \\
\hline - $65-84$ & $19(32,2)$ & $100(49,0)$ & $119(45,2)$ & \\
\hline - $>84$ & $6(10,2)$ & $36(17,7)$ & $42(16,0)$ & \\
\hline Başvuru Saat Aralığı n(\%): & & & & 0,292 \\
\hline - $0-8$ & $14(23,7)$ & $41(20,1)$ & $55(20,9)$ & \\
\hline - 8-16 & $16(27,1)$ & $78(38,2)$ & $94(35,7)$ & \\
\hline - $16-24$ & $29(49,2)$ & $85(41,7)$ & $114(43,3)$ & \\
\hline \multicolumn{5}{|l|}{ Komorbiditeler n(\%): } \\
\hline - Koroner Arter Hastalığı & $19(33,3)$ & $74(36,3)$ & $93(35,6)$ & 0,755 \\
\hline - Hipertansiyon & $23(40,4)$ & $57(27,9)$ & $80(30,7)$ & 0,076 \\
\hline - Diabetes Mellitus & $17(29,8)$ & $40(19,6)$ & $57(21,8)$ & 0,105 \\
\hline - Kalp Yemezliği & $11(19,3)$ & $40(19,7)$ & $51(19,6)$ & 0,946 \\
\hline - Kronik Obstruktif Akciğer Hastalığı & $7(11,9)$ & $13(6,4)$ & $20(7,6)$ & 0,169 \\
\hline - Kronik Böbrek Yetmezliği & $5(8,8)$ & $10(4,9)$ & $15(5,7)$ & 0,331 \\
\hline - Malignite & $7(12,3)$ & $24(11,8)$ & $31(11,9)$ & 1,000 \\
\hline - Demans & $6(10,5)$ & $16(7,8)$ & $22(8,4)$ & 0,589 \\
\hline - Serebrovasküler Hastalık & $2(3,5)$ & $16(7,8)$ & $18(6,9)$ & 0,378 \\
\hline Kardiyo-pulmoner Arrest Nedeni $n(\%)$ : & & & & 0,580 \\
\hline - Medikal & $41(69,5)$ & $155(76,0)$ & $196(74,5)$ & \\
\hline - Travma & $17(28,8)$ & $47(23,0)$ & $64(24,3)$ & \\
\hline - İntoksikasyon & $1(1,7)$ & $2(1,0)$ & $3(1,1)$ & \\
\hline Tanık Durumu n(\%): & & & & 0,480 \\
\hline - Halktan Kişi & $51(87,9)$ & $180(89,6)$ & $231(89,2)$ & \\
\hline - Tanıksız & $3(5,2)$ & $14(7,0)$ & $17(6,6)$ & \\
\hline - Sağlık Çalışanı & $4(6,9)$ & $7(3,5)$ & $11(4,2)$ & \\
\hline Olay Yeri n(\%): & & & & 0,687 \\
\hline - Ev & $48(82,8)$ & $151(75,5)$ & $199(77,1)$ & \\
\hline - Bakımevi & $1(1,7)$ & $1(1,7)$ & $3(3,0)$ & \\
\hline - Kamusal Alan & $8(13,8)$ & $37(18,5)$ & $45(17,4)$ & \\
\hline - İşyeri & 0 & $1(0,5)$ & $1(0,4)$ & \\
\hline - Sağlık Kuruluşu & $1(1,7)$ & $9(4,5)$ & $10(3,9)$ & \\
\hline
\end{tabular}


Tablo-2. Pandemi öncesi ve sonrası dönemde hastalara ait klinik bulguların değerlendirilmesi.

\begin{tabular}{|c|c|c|c|c|}
\hline & $\begin{array}{l}\text { Pandemi } \\
\text { Dönemi } \\
\text { n:59 }\end{array}$ & $\begin{array}{l}\text { Pandemi Öncesi } \\
\text { Dönem } \\
\text { n:204 }\end{array}$ & $\begin{array}{l}\text { Toplam } \\
\mathrm{n}: 263\end{array}$ & $\mathbf{p}$ \\
\hline $\begin{array}{l}\text { Sağlık Çalışanı ile Illk Temas } \\
\text { (dakika), ortanca (çeyrekler arası } \\
\text { aralık) }\end{array}$ & $10(10-10)$ & $15(10-22,5)$ & $15(10-20)$ & 0,034 \\
\hline Başvuru Kalp Ritmi n(\%): & & & & 0,465 \\
\hline - Şoklanabilir & $4(6,8)$ & $23(11,3)$ & $27(10,3)$ & \\
\hline - Şoklanamaz & $55(93,2)$ & $181(88,7)$ & $236(89,7)$ & \\
\hline $\begin{array}{l}\text { Olay Yerinde } 112 \text { Öncesi TYD } \\
\text { Uygulama } n(\%):\end{array}$ & & & & 0,033 \\
\hline - Var & $26(49,1)$ & $56(32,0)$ & $82(36,0)$ & \\
\hline - Yok & $27(50,9)$ & $119(68,0)$ & $146(64,0)$ & \\
\hline $\begin{array}{l}\text { Hastane Öncesi TYD Süresi } \\
\text { (dakika), ortanca, (çeyrekler } \\
\text { arası aralık) }\end{array}$ & $15(12,5-15)$ & $10(0-25)$ & $10(0-25)$ & 0,491 \\
\hline Hastaneye Geliş Şekli n(\%) & & & & 0,048 \\
\hline - 112 & $58(98,3)$ & $181(90,5)$ & $239(92,3)$ & \\
\hline - Diğer & $1(1,7)$ & $19(9,5)$ & $20(7,7)$ & \\
\hline $\begin{array}{l}\text { Hastane Öncesi Defibrilasyon } \\
\text { Uygulama } n(\%)\end{array}$ & & & & 0,656 \\
\hline - Var & $6(10,3)$ & $25(13,2)$ & $31(12,6)$ & \\
\hline - Yok & $52(89,7)$ & $164(86,8)$ & $216(87,4)$ & \\
\hline $\begin{array}{l}\text { Hastane Öncesi Orotrakeal } \\
\text { Entübasyon Uygulama n(\%) }\end{array}$ & & & & 0,367 \\
\hline - Var & $20(33,9)$ & $80(40,6)$ & $100(39,1)$ & \\
\hline - Yok & $39(66,1)$ & $117(59,4)$ & $156(60,9)$ & \\
\hline $\begin{array}{l}\text { Acil Servis'te ileri Havayolu } \\
\text { Sağlama } n(\%)\end{array}$ & & & & 0,650 \\
\hline - Evet & $38(64,4)$ & $122(60,7)$ & $160(61,5)$ & \\
\hline - Hayır & $21(35,6)$ & $79(39,3)$ & $100(38,5)$ & \\
\hline SDGD $n(\%)$ & & & & 0,030 \\
\hline - Evet & $13(22,0)$ & $76(37,3)$ & $89(33,8)$ & \\
\hline - Hayır & $46(78,0)$ & $128(62,7)$ & $174(66,2)$ & \\
\hline $\begin{array}{l}\text { SDGD süresi (dakika) ortanca, } \\
\text { (çeyrekler arası aralık) }\end{array}$ & $15(10-28)$ & $10(8-21,5)$ & $10(8-23)$ & 0,919 \\
\hline $\begin{array}{l}\text { Acil Servis'te KPR Süresi } \\
\text { (Dakika, Ort, SS) }\end{array}$ & $28,5 \pm 13,4$ & $26,2 \pm 16,0$ & & 0,058 \\
\hline Acil Servis'te Mortalite n(\%) & & & & 0,068 \\
\hline - Var & $52(88,1)$ & $156(76,5)$ & $208(79,1)$ & \\
\hline - Yok & $7(11,9)$ & $48(23,5)$ & $55(20,9)$ & \\
\hline Hastaneden Taburculuk n(\%) & & & & 0,384 \\
\hline - Var & $3(4,5)$ & $5(2,5)$ & $8(3)$ & \\
\hline - Yok & $56(95,5)$ & $199(97,5)$ & $255(97)$ & \\
\hline
\end{tabular}




\section{BULGULAR}

Çalışma için 2017, 2018, 2019 ve 2020 yıllarının 11 Mart - 01 Haziran tarihleri arasında başvuran ve acil serviste kardiyo-pulmoner resüsitasyon (KPR) yapılan 644 hasta incelendi. Hastane içi (n:362), ambulansta arrest gelişen ( $n: 13), 18$ yaş altı (n:5), Covid-19 PCR testi pozitif çıkan (n:1) hastalar dışlandığında 263 hasta çalışma popülasyonunu oluşturdu. Hastaların \%22,4'ünün (n:59) 2020, \%25,5'inin (n:67) 2019, \%27,0'inin (n:71) 2018, \%25,1'inin (n:66) 2017 yılında başvuruda bulunduğu belirlendi.

Çalışmaya dahil edilen hastaların \%66,9'unu (n:176) erkek cinsiyet oluşturdu. Gruplar arasında cinsiyet açısından farklııı saptanmadı ( $p: 0.346$ ). Yaş değişkeni incelendiğinde gruplar arasında farklılık gözlendi (p:0.010). Hasta yaş ortalamalarının 2020'de diğer yıllara göre daha düşük olduğu belirlendi. Yaş gruplarına göre değerlendirmede, <65 yaş altı HDKA sıklığının 2020 yılında diğer yıllara göre daha fazla olduğu gözlendi (\%57,6 - \%33,3, p:0.003). Eşlik eden komorbidite durumu gruplar arasında benzer bulundu. Hastaların özgeçmişlerinde koroner arter hastalığı (\%35), hipertansiyon (\%30), diabetes mellitus (\%21) en sık eşlik eden hastalıklar olarak belirlendi. Pandemi döneminde olay yerinde temel yaşam desteği (TYD) uygulama sıklığının diğer dönemlere göre daha fazla olduğu belirlendi (\%49,1 - \%32,0, p:0.033). Pandemi döneminde hastaların acil servise daha sık 112 ile getirildiği saptandı (\%98,3 - \%90,5, p:0.048). Spontan dolaşımın geri dönüşü (SDGD)'nin pandemi döneminde daha az olduğu gözlendi (\%22,0 - \%37,3, p:0.030). SDGD süresi yıllar arasında benzer bulundu. Sağlık çalışanı ile hastaların ilk temas süresinin pandemi döneminde daha kısa olduğu belirlendi ( $p: 0.034)$. Acil Servis'de KPR süresi pandemi döneminde daha uzun olarak belirlense de bu durum istatistiksel anlamlılık oluşturmadı. Çalışma verileri ayrıntıları Tablo-1 ve Tablo-2'de sunuldu.

\section{TARTIŞMA}

Ege Üniversitesi Tıp Fakültesi Hastanesi Acil Servisine 11 Mart - 1 Haziran 2020 ile 2017, 2018, 2019 yıllarının aynı dönemlerinde başvuran HDKA hastalarının karşılaştırıldığı çalışmamızda yıllar arasında benzer sayılarda HDKA vakasının görüldüğü belirlendi. Hastaların yaş verileri göz önünde bulundurulduğunda 2020 yılında başvuran hastaların yaş ortalamalarının diğer yıllara göre daha düşük ve 65 yaş altı HDKA vakalarının diğer yıllara göre daha fazla olduğu saptandı. Hastalara olay yerinde geçmiş yıllara kıyasla daha sık TYD basamaklarının sağlık ekipleri gelinceye kadar uygulandığı belirlendi. Vakalara sağlık çalışanlarının ilk temas süresi pandemi döneminde daha kısa olarak bulundu. HDKA vakalarının hastaneye getiriliş şekli 2020 yılında daha çok 112 aracılığı ile oldu. SDGD diğer yıllara göre 2020'de daha azdı. Olay yeri, başvuru ritmi, hastane dışı orotrakeal entübasyon ve defibrilasyon uygulaması gibi HDKA varlığında sağ kalım üzerine etki olasılığı bulunan faktörler arasında yıllar arasında fark saptanmadı.

Avustralya, Fransa, İtalya, İspanya ve ABD gibi gelişmiş ülke verilerinden oluşan bir derlemede 2019 yılı ile karşılaştırıldığında pandemi döneminde hem HDKA vakalarının görülme sıklığında hem de mortalite oranlarında artış olduğu bildirilmiştir. Yine bu çalışmada pandemi öncesi dönem ile karşılaştııılığında travma ilişkili HDKA vakalarında, halktan kurtarıcıların müdahale oranında, tanıklı kardiyo-pulmoner arrest durumunda, şoklanabilir ritim varlığında, hastane öncesi havayolu yönetiminde entübasyon uygulama ve sağ kalım sıklığında azalma belirlenmiştir (4).

Spontan dolaşımın geri dönüşünün birincil sonlanım noktası olarak belirlendiği, Covid-19 pandemisinin direkt ve indirekt etkilerinin araştırıldığı ve Güney Kore verilerinin de dahil edildiği bir derlemede ise gerek enfeksiyonun etkileri gerekse sağlık bakım hizmetlerindeki tıkanıklıklara bağlı sekonder sorunlar nedeni ile pandemi öncesi dönem ile karşılaştırıldığında HDKA vakalarının prognozlarının daha kötü olduğu belirlenmiştir (5).

Covid-19 enfeksiyonu görülme sıklığı ve mortalite verileri yüksek belirtilen bu gelişmiş ülke verilerinin aksine Avustralya'nın Victoria eyaleti verilerine dayanan ve pandemi yoğunluğunun Dünya geneline göre düşük olarak bildirildiği bir çalışmada ise HDKA sıklığı pandemi öncesi döneme göre değişmemekle birlikte hastane öncesi sağlık hizmetlerinin sunumundaki gecikmeler nedeni ile SDGD, sağ kalım gibi faktörlerde pandemi öncesi döneme göre azalma bildirilmiştir (6). Aynı şekilde ABD'nin Covid-19 insidansı düşük olan bir bölgesinde gelişen HDKA vakalarının 2019 yılı verileri ile karşılaştırıldığı bir çalışmada HDKA insidansında değişiklik olmamakla birlikte; halktan kurtarıcıların müdahale sıklığında, otomatik eksternal defibrilatör (OED) kullanımında, hastaneden 
taburculukta azalma ve hastane öncesi sağlık hizmeti sunumunda gecikme bildirilmiştir (7).

Literatür verileri göz önünde bulundurulduğunda, ülkemizdeki Covid-19 enfeksiyon sıklığına İzmir il merkezi ve ilçelerinin etkisi ile ilişkili her ne kadar elimizde kanitlar olmasa da gerek acil servisimize başvuran hasta sayısındaki azalma ve gerekse HDKA olarak başvuran hastalarda değişiklik olmaması bölgemizdeki etkilenmenin bahsedilen ülkelerde olduğu kadar yüksek olmadığını düşündürmüştür. Bununla birlikte, Covid-19 enfeksiyonu sıklığının az olduğu bölgelerdeki acil sağlık hizmetlerinin sunumu ile ilgili yaşanan; halktan kurtarıcıların müdahale sıklığında, OED kullanımında azalma, hastane öncesi sağlık hizmet sunumunda gecikme gibi sorunlar geçmiş yıllar ile karşılaştırıldığında çalışmamızda belirgin bir farklılık göstermemiştir. Aynı zamanda acil serviste entübasyon uygulaması ve resüsitasyon süresi gibi parametrelerde pandemi öncesi dönem ile karşılaştırıldığında olumsuzluk saptanmamasına sağlık çalışanlarının kişisel koruyucu ekipmana ulaşmakta zorluk çekmemeleri ve negatif basınçlı alanda hastalara müdahalede bulunmalarının etki ettiğini düşünmekteyiz. Pandemi öncesi döneme göre olay yerinde daha sık TYD uygulamalarının yapılması, 112 ekiplerinin olay yerine daha erken ulaşması gibi farklılıkların pandemi dönemindeki kısıtlamaların sonucu olarak TYD uygulayıcılarının olay yerinde hazır bulunması ve trafik akışının daha hızlı olması ile ilgili olabilir. Bununla birlikte hastalara daha fazla TYD uygulaması yapılmasına rağmen SDGD veya mortalite gibi değişkenlerde iyileşme gözlenmemesi altta yatan medikal durumun ciddiyeti veya TYD kalitesi ile ilişkili olabilir

Çalışmamızın dikkat çekici sonuçlarından biri HDKA olarak başvuran hastaların yaşlarının diğer yıllara göre daha düşük olmasıdır. Bu durum azalan acil servis ve hastane başvuruları ve hastane öncesi sağlık hizmetlerinin sunumunda diğer yıllara göre olumsuz bir farklılık olmadığı göz önünde bulundurulduğunda, pandeminin direk etkilerinden ziyade kısıtlamalar veya hastanede enfeksiyon kapma korkusu gibi faktörlerin bir sonucu olarak hastaların sağlık hizmetinden zamanında faydalanamamaları sonucu gerçekleşmiş olabilir. Gelecek çalışmalarda bu konunun incelenmesinin pandemi durumlarında sağlık hizmetlerinin devamlılığının sağlanması konusunda planlamaların yapılmasına katkı sağlayabileceğini düşünüyoruz.

Çalışmamız retrospektif nitelikte olduğu için bazı kısıtlılıklar bulunmaktadır. Değişkenler dosya taraması üzerinden değerlendirildiği için hastayı birincil takip eden hekim ve alandan hastayı getiren 112 görevlisinin verdiği bilgiler dikkate alınmıştır. HDKA vakalarını 112 Komuta Kontrol Merkezi'nin pandemi döneminde başka merkezlere yönlendirip yönlendirmediği bilinmemektedir. HDKA vakalarında PCR testi negatif olan hastalarda testten kaynaklı yanlış negatiflikler Covid-19 enfeksiyon tanısının atlanmasına neden olmuş olabilir.

\section{SONUÇ}

Ege Üniversitesi Tıp Fakültesi Hastanesi Acil Servisine başvuran HDKA vakalarının sıklığında pandeminin erken döneminde değişiklik gözlenmemiştir. Sağlık hizmetlerinin HDKA vakalarına sunumu ile ilgili sistemsel olumsuzluk belirlenmemiştir. Pandemi öncesi döneme göre HDKA vakalarının yaş ortalamalarının azalmasının nedenleri araştııılmalıdır.

Çıkar çatışması: Yazarlar çıkar çatışması beyan etmemişlerdir.

\section{Kaynaklar}

1. T.C. Sağlık Bakanlığı, Halk Sağlığı Genel Müdürlüğü. COVID-19 (SARSCoV-2 Enfeksiyonu) Genel Bilgiler, Epidemiyoloji ve Tanı. Bilimsel Danışma Kurulu Çalışması. Serolojik testler, p 14-15. (29 Haziran 2020). Available from: URL: https://covid19.saglik.gov.tr/Eklenti/38597/0/

2. Açıksarı K, Kınık K. Türkiye'de bir Eğitim Araştırma Hastanesi Acil Servisinde Koronavirus Hastalığı 2019 Pandemi Sürecinin Yönetimi ve Sonuçları (TR/ENG). Anadolu Klin. 2020; 25 (Special Issue on COVID 19): 263-283.

3. İlhan E, Oztop M, Üreyen O, Yıldırım M. Covid-19 Pandemisinin Genel Cerrahi Kliniğinde Acil Ve Elektif Cerrahi Girişimlere Olan Etkisinin Değerlendirilmesi: Kesitsel Çalışma. Ankara Eğitim ve Araştırma Hastanesi Tıp Dergisi. 2020; 53 (3): 202-205. 
4. Lim ZJ, Reddy PM, Afroz A, Billah B, Shekar K, Subramaniam S. Incidence and outcome of out-of-hospital cardiac arrests in the COVID-19 era: A systematic review and meta-analysis. Resuscitation. 2020 Dec; 157: 248-258.

5. Scquizzato T, Landoni G, Paoli A, et al. Effects of COVID-19 pandemic on out-of-hospital cardiac arrests: A systematic review. Resuscitation. 2020 Dec; 157: 241-247.

6. Ball J, Nehme Z, Bernard S, Stub D, Stephenson M, Smith K. Collateral damage: Hidden impact of the COVID19 pandemic on the out-of-hospital cardiac arrest system-of-care. Resuscitation. 2020 Nov; 156: 157-163.

7. Evanado AU, Harpriya SC, Arayik S, et al. Out-of-Hospital Cardiac Arrest Response and Outcomes During the COVID-19 Pandemic. J Am Coll Cardiol Clin Electrophysiol. Oct 28, 2020. Epublished DOI: 10.1016/j.jacep.2020.08.010. 